\title{
Irrigation and Society in the Upper Río Grande Basin, U.S.A: A Heritage of Mutualism
}

\author{
José A. Rivera ${ }^{1}$, Juan Estevan Arellano², Enrique R. Lamadrid ${ }^{1}$, and Tomás Martínez Saldaña 3 \\ ${ }^{1}$ University of New Mexico, Albuquerque, NM, USA ${ }^{2}$ Acequia Junta y Ciénaga, Embudo, NM, USA \\ ${ }^{3}$ Colegio de Postgraduados, Texcoco, Mx \\ jrivera@unm.edu, estevanarellano@gmail.com, lamadrid@unm.edu,tms@colpos.mx \\ Corresponding author: jrivera@unm.edu
}

\begin{abstract}
The acequias of the upper Río Grande are more than just irrigation canals. They also allocate and manage water for the community of landowners in the system. After four centuries of use, the acequias persist into modern times with their founding principles intact: self-government, local autonomy, internal rules for operating procedures, and a strong sense of mutualismo or communal responsibility. They have endured since Spanish colonial settlement, and have maintained continuity of a water culture surviving political-administrative changes under three sovereigns, Spain (1598-1821), Mexico (1821-1848), and the United States (1848Present). Despite stressors of climate variability, demographic changes, urbanization, and economic modernity, the acequia parciantes hold onto, maintain, and defend their shares of water in the acequia madre. Most of these irrigation works still function as before, zanjas carved out of the land to shape the edges of the semi-arid terrain and extend the riparian zones for multiple uses. Will they survive the pressures to move water to higher economic values such as municipal growth in the urban centers, water shortages among competing users, and the effects of drought evidenced in recent years? Similar to the irrigation communities of medieval Valencia that were modeled after the craft guilds of that era, the acequias of the upper Río Grande have ties to other solidarities, namely, the cofradias and mutualista societies characterized by common attributes: the adoption of written rules and regulations, the election of officers for executive functions, and operating procedures that are self-determined. Mutualism in the acequia culture, coupled with recovery of the Spanish language, could be the key to adaptation when new challenges emerge in future scenarios of unexpected change.
\end{abstract}

Keywords: Acequias of the upper Río Grande, mutualism, and water governance resilience

Resumen. Regadio y sociedad en la cuenca del Alto Rio Grande, E.U.A.: La berencia mutualista. Las acequias del alto Río Grande son mucho más que canales de riego. También proporcionan y manejan el agua para la comunidad de terratenientes del sistema. Después de cuatro siglos de uso, las acequias persisten hasta los tiempos modernos con sus principios originales intactos: auto-gobierno, autonomía local, reglas internas para los procedimientos de operación y un fuerte sentido de mutualismo o responsabilidad comunal. Han durado desde la colonización española, sosteniendo una cultura de agua que ha aguantado tres gobiernos, España (15981821), México (1821-1848) y los Estados Unidos (1848 hasta el presente). A pesar de los desafíos de variabilidad del clima, cambios demográficos, urbanización y modernización económica, los parciantes de la acequia conservan, mantienen y defienden sus derechos de agua de la acequia madre. La mayoría de estos sistemas de riego todavía funcionan como siempre, con zanjas excavadas que marcan los límites del terreno semi-árido y extienden las zonas ribereñas para usos múltiples. ¿Sobrevivirán las presiones para asignar el agua para usos de más valor económico como el crecimiento de los centros urbanos, la escasez de agua entre usuarios y los efectos de la creciente sequía de los últimos años? Parecidos a las comunidades de riego de Valencia medieval que se organizaban como los gremios de la época, las acequias del alto Río Grande se vinculan a otras asociaciones como las cofradías y sociedades mutualistas caracterizadas por estos atributos en común: la adopción de reglas y normas escritas, la elección de oficiales para funciones executivas y procedimientos de operación autodeterminados. El mutualismo en la cultura de las acequias, vinculado con la recuperación del idioma castellano, pueden ser la clave de adaptación cuando emergen nuevos desafíos en los futuros escenarios de cambios inesperados.

Palabras clave: Acequias del alto Río Grande, mutualismo y resistencia del gobierno del agua. 


\section{Introduction}

The community-based acequias in the upper Río Grande basin are the oldest water management institutions in the United States of European origin. These irrigated agrosystems date to the time of first Spanish settlement in the northern provinces of Nueva España during the late sixteenth century with the first Juan de Oñate colony in 1598 at San Gabriel and expanded after the Reconquista of 1692 when Governor Diego de Vargas regained the capital city of Santa Fe and established the Villa Nueva de Santa Cruz de Españoles Mexicanos del Rey Señor Carlos Segundo in 1695. At the time, the borderlands of the north encompassed a vast semi-arid territory rich in natural and mineral resources but was short on water supply. In New Mexico the Rocky Mountain province of Colorado joins the great Chihuahuan desert from the south and the Llano Estacado from the plains of Texas on the east. Cartographers from the colonial period often depicted the Provincias Internas del Nuevo México as an indeterminate region encompassing most of the present Southwestern United States bounded on the northwest by tierra despoblada and on the northeast by tierra incognita. Early in his term as the newly appointed Governor, Don Diego de Vargas made note of the extreme isolation and inhospitable environment of el Reyno del Nuebo México. In April of 1692 he wrote a letter from El Paso del Río del Norte to his family in Spain stating that he found himself "exiled to this kingdom at the ends of the earth and remote beyond compare" (Letter of April 9, 1692 cited in Kessell 1989, transcription of original Spanish: "No puede Obrar Mas mi fineza que es el haverme Desterrado a este Reyno Ultimo de el Mundo y Remoto Sin Ygual," pp. 168 and 375).

Due to conditions of aridity, Spanish colonization policies required that settlers locate their communities in the vicinity of water essential for permanent occupation. To receive grants of land, mercedes de tierra, the provincial government instructed that they must also organize for self-sufficiency, mutual aid, and their common welfare. The irrigation technology employed by the waves of pobladores was gravity flow of surface water from rivers diverted to head gates through a system of earthen canals or acequias. The settlers constructed acequias in most of the present American Southwest: Texas, New Mexico, Colorado, Arizona, and California. However, it was in La Provincia de San Felipe del Nuevo México along the Rio Grande del Norte that settlement policies were the most effective, particularly with regard to the establishment of civilian towns and agricultural colonies. Once constructed, the local acequia de común (commons ditch) wedded the appropriators into a hydraulic society, as currently expressed in the phrase, "Water is the lifeblood of the community." Other forms of mutualismo (reciprocal mutual aid) co-exist in the upper Río Grande communities, and together with the acequias they continue to perpetuate a sense of place while maintaining a cultural heritage rooted in the principle of mutual help: cofradias de penitentes, sociedades mutualistas, and the acequias de común

In the cases presented here, acequias de común, cofradias de penitentes, and sociedades mutualistas, each one is a distinct form of mutual aid collective, but nonetheless they share a number of key characteristics: autonomous local governance, election of officers, operational rules and procedures written in Spanish, rituals that bond the membership, and solidarity of the group. All three forms have survived for two or up to more than four centuries to include periods of rapid social change, transformations in the legal-political environment, and a barrage of pressures brought forth by the forces of modernity in a post-industrial society. Initial settlements in the region were dispersed along watercourses, and absent governmental aid, social and economic security depended on the mobilization of resources based on the traditions of self-reliance embedded in culture of ayuda mutua. Under conditions of a harsh frontier, the people had to fend for themselves, and over the 
generations they successfully organized corporate villages, religious brotherhoods, mutual aid societies, and other protective associations to resist outside forces and insure their "sacred right of self-preservation" (Rosenbaum 1981).

\section{Acequias de común/Community irrigation ditches}

Acequia irrigation systems employed in the northern province of Nuevo México were melded from diverse sources. Historians agree that these antecedents included the irrigation practices common to the arid regions in the south of Spain, particularly Andalusia, Castilla and Valencia, based on traditions from the Roman period; the superimposition of AraboBerber customs and operating procedures during the seven centuries of occupation of Spain by Muslims from north Africa and the Middle East; the influence of Pueblo Indian agriculture as observed by early Spanish expeditions into northern Nueva España; and the irrigation horticulture of Mesoamerica brought by Mexican Indians who accompanied the Spanish caravans along the Camino Real de Tierra Adentro (Glick 1970; Martínez Saldaña 1998).

Led by adelantado Juan de Oñate in 1598, caravans of Spanish-Mexican settlers and Mexican Indian allies came up the Camino Real from Mexico City, traversed the Jornada del Muerto north of El Paso del Norte, and finally reached the confluence of the Río Grande del Norte and the Rio de Chama (Martínez Saldaña and Rivera 2008). Here, they searched for perennial streams of water fed by distant snow packs in the alpine sierras to the north. Without the aid of survey instruments or modern tools, the early settlers engineered irrigation works superimposing zanjas on the desert landscape all by collective human labor. The first step, as instructed by the ordenanzas de descubrimiento (Laws of the Indies 1573; Arellano 1997), was to locate a bend in the river or another suitable feature to build a diversion structure from which to capture water and turn it into ditches on one or sometimes both banks of the natural watercourse. Constructed of locally available materials such as forest timbers, brush and rocks, these irrigation works defined the landscape and demarked the boundaries for irrigation off the main canal and its laterals for several miles downstream extending the riparian zone beyond the narrow confines of the natural channels. These technologies of construction and irrigation methods were replicated by the successive waves of settlers into the tributaries of the Río Grande fostering the growth of agrarian communities along the Camino Real de Tierra Adentro from El Paso del Norte (now Ciudad Juarez) to Santa Fe and later to the Taos Basin and parts of southern Colorado (Rivera and Martínez 2009; Peña 1998).

For the establishment of Santa Fe in 1610, Spanish officials were accompanied by Tlaxcalteca Indians, themselves expert irrigators and horticulturalists who doubled as farmer soldiers in a military and political alliance with the colonizers. Since the middle of the sixteenth century, hundreds of Tlascalan families had traveled in caravans along " $/ a$ Ruta de la Plata" (the Silver Trail) from Tlaxcala, Mexico, to the northern borderlands where they established agricultural colonies at strategic locations such as San Luis Potosí, Querétaro, Zacatecas, Guadalajara, Durango, Saltillo, Colotlán, Monterrey, and Parral, as well as other population centers tied to the economy of silver mining and trade (Martínez Saldaña 1998). Further to the north, a band of Tlascalans built la Iglesia de San Miguel at the southern entrance to Santa $\mathrm{Fe}$, and they may also have constructed the acequia para regadio (irrigation ditch) on the banks of the Rio de Santa Fe to grow crops needed for the fledgling capital city. Later, in 1767, they were credited with having founded their own community, depicted in the José de Urrutia map as the "Pueblo o Barrio de Analco que debe su origen a los Tlaxcaltecas que acompañaron a los primeros Españoles que entraron a la Conquista de este Reino" 
(Town or neighborhood of Analco that owes its origins to the Tlascalans who accompanied the first Spaniards who came in the conquest of this Kingdom). By this time in the latter half of the $18^{\text {th }}$ century, the initial group of Tlascalan settlers had become integrated into colonial society as they blended into the larger Santa Fe culture of españoles mexicanos and other Mexican Indians of diverse origins who had also arrived with the conquistadores (Martínez Saldaña 1998, 2004).

During the Spanish colonial period, 1598-1821, water resources were owned and managed by a community of landowners, pobladores all irrigating from a single main canal similar to the organizational arrangements of la comuna of medieval Valencia in southern Spain. According to Glick (1970), the comuna was the basic irrigation unit that distributed water, maintained the canal system, and elected a cequier to administer the ordenanzas of the canal. In structure, these Spanish irrigation communities adopted institutional forms, executive procedures and written ordinances of internal governance similar to the craft guild organizations that pre-existed just after the Christian Reconquest when the Valencians took control of the irrigation canals that had been developed by the Muslims during their occupation of Spain. As solidarities, the guilds were the most immediate models of selfgovernment for the Valencian farmers to adopt since the Tribal governance of the Muslims based on clans and other kinships would not have been the norm to follow (Glick 1970, 2003).

In La Provincia del Nuevo México, the initial settlers too organized themselves as a community of irrigators isomorphic with the village itself: the owners of property with irrigable lands who collectively viewed themselves as "el pueblo" or town. Each acequia system was built as a commons where the irrigators banded together as a public works labor force, a union of citizens or mancomunidad. When a community land grant was issued, the vecinos (citizen residents) were required to construct an irrigation system by mobilizing communal labor, as in the decree of 1794 establishing the San Miguel del Bado Land Grant. Here the fifty-two petitioners were ordered by the Alcalde de Santa Fe: "That the construction of their Plaza, as well as the opening of the ditches, and all other work that may be deemed proper for the common welfare shall be performed by the community with that union which in their government they must preserve" (Leonard 1970). Construction of the diversion dam upstream and the acequia madre through and below the community was only the first step; annually, repairs would be needed, as would the ritual of cleaning the acequias early each spring at the start of the irrigation season (Rivera 1998; Rodríguez 2006). In addition, the landowners who cooperated in these mutual aid efforts agreed to administer the ditches, divide the water into shares proportionate to acres of land irrigated by each parciante, elect a water official to implement local regulations, and very importantly, resolve their own conflicts and disputes (Meyer and Brescia 1998).

In the view of Meyer and Brescia (1998), the mutual aid function of the mancomunidad, was primary and akin to the religious societies of the times:

Over time the mancomunidad... grew from an instrument of physical survival to one of cultural survival. Just as the ditch itself tied the fields together, the association tied the rural neighborhood together, reinforcing compadrazgo, imparting to each village a distinct identity, and offering itself as a mechanism for mutual aid during crises or times of need. In essence it blended the cultural and the material into a kind of secular cofradia, a confraternity that formed the nucleus of rural life in Hispanic New Mexico. 
Of necessity, and key to the success of each irrigation system, the community settlers did not adhere to a prescribed set of regulations from a central authority, and instead they negotiated institutional arrangements among the collective that they called "arreglos," operational rules that were specific to the water delivery requirements of the shared canal and its laterals. The taking of water during the initial saca de agua carried forward into the local customs and traditions for water distribution and the operations and maintenance of the irrigation works and the annual limpia or ditch cleaning during the early spring just before the expected run-off season. This self-organized enterprise wedded the irrigators into a shared institution for water management that bonded them as a hydraulic society, a living culture of water based on cooperation and mutualism. As noted by Glick (2013), the acequias of New Mexico persist as consensual communities: autonomous institutions with self-governance based on guild-like administrative practices and operating procedures determined by the parciantes themselves and not by outside officials.

\section{Cofradías de penitentes/Penitent brotherhoods}

For many generations the acequias coexisted with other mutualidades that permeated village life and the social structure of the bispano community: the civic-religious cofradias during the Spanish colonial and Mexican periods, followed by the sociedades mutualistas that proliferated at the turn of the twentieth century under United States jurisdiction, 1880-1930s. The precursors to the secular mutualistas were the cofradias of northern New Mexico and southern Colorado known as penitentes, or formally, "La Fraternidad Piadosa de Nuestro Padre Jesús Nazareno." Due in part to the lack of sufficient Catholic priests, the penitentes associated for religious purposes through prayer and bodily penance and, importantly, for charitable works within the local villages where they were organized. The members of these brotherhoods were hermanos, lay Catholic men who conducted penitent rituals, including self-flagellation and simulated crucifixions during Lenten season and Holy Week, and other religious practices throughout the year (Weigle 1970, 1976).

The penitente societies formally emerged in the upper Río Grande in the late 1790s, although antecedents of Catholic Church confraternities, lay sodalities approved by the Bishop, had been present since early colonial times and some continue to the present. Catholic lay societies include the confraternities of Our Lady of the Rosary, the Holy Family, Our Lady of Mt. Carmel, the Holy Altar, St. Joseph Patriarch, the Sacred Heart of Jesus, St. Francis Assisi, and others that organized around the care and veneration of a local shrine (Briggs 1988). The penitent societies, however, were independent groups of hermanos who associated to commemorate the passion and death of Christ outside of the supervision of the Catholic Church hierarchy headquartered in the Archdiocese of Durango hundreds of miles from Santa Fe. In remote Nuevo México, these societies were modeled after the sixteenth century cofradias brought by the Spaniards into Mexico City and later to the province of Nueva Vizcaya (now Durango and Chihuahua) where some of the mutualidades controlled water, farmlands, orchards, vineyards, and livestock while ensuring both the material and spiritual welfare of the agrarian communities (Lamadrid 2008; Martínez Saldaña and Rivera 2008). By the middle 1850s the penitentes of New Mexico had extended into the villages of the San Luis Valley as settlement patterns dispersed outward from the Taos Basin, each time further away from the Franciscan priests who tended primarily to the Pueblo Indians in the missions (Steele and Rivera 1985).

The village penitentes held their meetings in a ritual chapel called "La Morada," and the officials who directed the society's activities were usually elected by popular vote similar to 
procedures followed by the medieval craft guilds in Spain. In addition to the Hermano Mayor, who held the highest local authority, other organizational officers included: a Secretario as the clerk custodian of the confraternity records and rule book; a Mandatorio or treasurer and collector of dues; a Celador who acted as a sergeant-at-arms; an Enfermero who cared for the sick and performed charitable works; a Rezador who read prayers at important ceremonies; a Maestro de Novicios who instructed and supervised the novices petitioning for admission; a Sangrador who inflicted whip lashes on the backs of novices; a Pitero who played a flute as musical accompaniment during services, and other officials who performed specified religious duties during penitential observances (Weigle 1970).

The cofradias de penitentes surfaced at a time when spiritual administration was too distant from the locus of municipal life in the upper Río Grande. Of necessity these hermanos developed autonomous societies outside the hierarchy of the Catholic Church as they undertook religious practices of their own native design and established constitutional rules of self-government. With communal labor, they built their own private chapels, moradas, that also served as meeting halls to conduct business affairs and develop various programs of charity to villagers in need. To construct the moradas they used local materials: adobe bricks and stones for the foundations and walls; mud flooring; vigas, or wood beams, from nearby forests for the ceiling and roof supports; and rough lumber for the small window frames and the entrance doors (Buxó i Rey 2003).

Throughout the phases of development, the benevolent activities of the cofradias remained consistent village to village, expressing their core belief in caridad: ministering to the sick and elderly, providing food and emergency assistance, arranging funeral and burial ceremonies, assisting widows and orphaned children, helping with agricultural chores, punishing members who violated village norms, and occasionally settling village disputes (Knowlton 1969). To care for the ill, the hermanos appointed a Nurse (Enfermero) from amongst the membership. This officer was charged with visiting the sick, performing works of mercy, reporting back on specific family needs, and mobilizing both spiritual and material assistance to be provided by the local brotherhood. If cash were needed for medical bills or other family expenses, the Enfermero requested that the Hermano Mayor draw from the common fund of the society or solicit donations from the members (see "Rules for the Nurse," Chama, New Mexico, in Steele and Rivera 1985). If certain hermanos were not able to contribute cash, they often provided in-kind help or other goods and services such as firewood for home use, a team of horses and a wagon to help with farm chores, or donations of staple foods grown on the local farms such as wheat, potatoes, beans, peas, or grains (Morada de los Pinos Journal in Archuleta 2003).

In the event of death, the hermanos as a group prepared the deceased, conducted a velorio, organized rosarios, dug the grave, led a procession to the campo santo after the funeral mass, sang alabados, and performed the burial ceremonies (Kutsche and Gallegos 1979). Should cash assistance be needed by the surviving widow, the hermanos organized a collection or make an outright donation from a common fund. Alternately, families in needs would be provided with direct food assistance and clothing taken from the morada storehouse of grain, flour, potatoes, shoes and other articles of clothing (Barker 1924). After the introduction of the cash economy into the villages, some councils of the penitentes formalized the burial assistance program by way of a modest insurance policy administered by a finance committee, a bonded treasurer, and a system of lump sum benefit payments (Steele and Rivera 1985), classic functions duplicated by the larger sociedades mutualistas in the region at the turn of the twentieth century. 
Lenten observances, especially flagellation and other rites of worship, eventually caused the Catholic Church authorities in Durango and later the Archbishop of Santa Fe to question the legitimacy of the brotherhoods and view them as disobedient "secret societies" out of step with church orthodoxy. Archbishops and local priests alike did not recognize the important mutual aid and community functions performed by the bermanos and instead chose to condemn their use of corporal penances and other perceived abuses that in their view endangered the members themselves as well as the legitimate church congregations. As a reaction, the brotherhoods protected themselves by imposing even more strict internal controls to retain their autonomy and secrecy. Attempts to ban the members from receiving the holy sacraments or to submit to Church authority were not successful; enforcement of these and other guidelines were sparsely implemented and largely ineffective (Weigle 1976; Briggs 1988).

In the post-World War II era, accelerated social and economic change reduced the isolation of the penitente villages. Membership rolls declined as the elders passed away, and the younger generations moved to urban employment centers and joined other organizations more in line with modern American society. The many acts of charity provided by the hermanos in earlier times gradually became supplanted by other forms of mutualismo and by government welfare programs. Some penitent brotherhoods, however, have survived into the twenty-first century, maintaining their moradas and practicing their religious beliefs in scores of villages located principally within the Río Arriba district, the regional bispano homeland of northern New Mexico and southern Colorado. Some have successfully obtained historic preservation funds to repair and restore their moradas for use by future generations, such as La Morada de San Francisco in the San Luis Valley along with the moradas at Fort Garland and García. In New Mexico the moradas at Arroyo Seco, Talpa, Abiquiu, Tierra Amarilla, and other communities continue to function and have been utilized and maintained continuously, as have the moradas of San Luis, San Antonio, and Trinidad, Colorado (See Archuleta 2007 for a list of seventy-three moradas that are still active and his photo documentation of processions, structures, religious artifacts, and devisas).

\section{Sociedades mutualistas/Mutual aid societies}

In common with the acequia associations and the cofradias de penitentes, the sociedades mutualistas of the late $19^{\text {th }}$ century valued the customs of repartimiento, auxilio, and caridad, forms of sharing that survived among the people clustered in isolated villages distant from the larger cities and government centers (Rosenbaum 1981). For many generations, these vecinos had banded together and replicated traditional forms of cooperation familiar to them in order to solve problems and mobilize resources for personal stability and the common welfare. When necessary, the village people created new forms of voluntary mutual help, adopted rules for self-government, elected their own officers, and pooled their resources to finance local aid to families in need as community-based strategies of social security (Buxó i Rey 1997). During the period of industrialization that followed the introduction of the railroad, c. 1879, membership within the acequias, cofradias de penitentes and the mutualistas often overlapped, as the parciantes and hermanos were of the same village and culture. Unlike the colonial period when the acequia associations were the main force in the social and technical functions of community life, the American territorial period after 1848 brought stricter water regulations and new institutions competing with the acequias, making evident the need for villagers to protect their traditional ways and resist change as best they could. They responded by organizing sociedades mutualistas, mutual aid societies that flourished and proliferated dramatically during 1880-1911, and well into New Mexico statehood granted in 1912 (Rivera 2010). 
The sociedades mutualistas were established almost a century after the inception of the cofradias de penitentes, but they adopted similar rituals and maintained the charitable works. They recited Catholic prayers at meetings, conducted funeral and burial services for deceased members, performed acts of charity at the village level, and promulgated rules of ayuda mutua. Most of the early sociedades mutualistas originated as burial funds at a time when commercial life insurance was not available in the isolated rural communities, and soon, other functions were added such as sponsoring literary and debate societies for the enlightenment and educational advancement of members, and providing economic assistance during times of illness, unemployment, or when members were confronted with other misfortunes of life. Often the members took care of agricultural chores such as irrigating a neighbor's fields or harvesting crops if their hermano was hospitalized or too ill to work his own land and farm. Like the penitent brotherhoods, the mutualistas too built their local meeting halls in the vernacular architecture: rectangular or linear floor plans, flat or pitched roofs, and the use of adobes, vigas, rocks and other local materials for construction. For the provision of social services, they designed local projects of assistance, obras de caridad; appointed an Enfermero to visit the sick; recorded their rules and minutes in journals; displayed their membership ribbons or devisas at public ceremonies and conventions; and at the end of life, they held vigil over the deceased hermanos, dug their graves, paid their respects, and then provided financial help to the widows, orphans and other survivors (Rivera 2010).

In the agricultural districts mutualista organizations were formed in the defense of land and water rights following the introduction of the railroad in 1879 when land speculators, cattle companies, mining interests and other capitalist investors from "los estados" to the east entered the region seeking to exploit its mineral, natural and labor resources. The rise in Anglo American population, following the United States War of 1846-1848 against Mexico, coupled with the imposition of a new legal-administrative system of land tenure under the terms of U.S. Conquest, set the stage for land struggles between the native hispanos and the newcomer immigrants. Some Spanish and Mexican period land grants were privatized by legal and sometimes illegal shenanigans; most others were stolen or federalized by the U.S. courts into the public domain. In the community grants, hispanos lost access to their communal lands in the forests and the open rangelands for pasturing of their sheep, goats, and cattle. The loss of this subsistence base induced great changes that placed villagers in a dependency relationship to the political-economic forces in the outside world, making them "foreigners in their native land" (Briggs 1988; Weber 1973).

Soon, many hispanos were transformed from landowner ranchers and farmers to wage laborers employed in mining, railroad construction, timbering, commercialized agriculture, and urban service industries where they took the brunt of exploitation and wage discrimination (Rivera 2010). To resist encroachment and protect their land and water resources, hispanos organized mutual benefit and protective associations. In 1888 the acequia farmers of Cerro in Taos County formed "La Asociación de Mutua Protección y Mutuo Beneficio de la Plaza de Cerro de Guadalupe" to assert and defend their rights to the waters of the Ritos del Latir and access to the mountains and grazing ranges within the boundaries of their community land grant (Constitución y Articulos de Incorporación 1888). A decade later, the settlers of Costilla north of Cerro similarly organized their own "Asociación Defensiva de los Pobladores de los Terrenos del Río de Costilla" in order to affirm their rights as landowners and irrigators "cultivando las tierras, construyendo presas y acequias de regadío, edificando casas... de este modo ocupando dicho terreno con sus montes, pasteos, sus fuentes de agua en beneficio común" (cultivating the lands, constructing dams and irrigation ditches, building houses... in this way 
occupying said land with its forests, pastures, with its water sources for their common benefit) all against foreign companies claiming the land (Constitución de la Asociación Defensiva 1902).

In the San Luis Valley of Colorado, hispanos established "La Sociedad de Protección Mutua de Trabajadores Unidos" in 1900 to help workers during times of unemployment, illness, or met the needs of widows and orphans, and also to combat wage and racial discrimination in the railroad and mining industries emerging at the time. Many of the members were also traditional farmers, and like their acequia neighbors in nearby Costilla and Cerro, they united "para protegerse contra las injusticias de los tiranos y de los déspotas, de los usurpadores de la ley y de la justicia, de los ladrones de vidas, honras y propiedades..." (...to protect each other against the injustices of tyrants and despots, the usurpers of law and justice, and those who steal our lives, honor and property, Preámbulo, Constitución y Reglamento de la SPMDTU 1922). As an organization of trabajadores unidos, the SPMDTU turned its attention to services not available from employers or government: cash-subsidy benefits to members when they were unable to work due to illness or injuries; short-term loans in times of family crises or medical emergencies; and funeral benefits paid to widows, orphans, and survivors at the time of a member's death. By the late 1930s, in the midst of the Great Depression, La Sociedad had already commissioned fifty-four local councils, with thirty-one in Colorado and twenty-three in New Mexico and three others in Utah during the 1940s (Rivera 2010; Buxó i Rey 1997).

From among hundreds of mutualistas, only a few have survived into the twenty-first century, but like the hundreds of acequia associations, they continue to govern their own affairs and maintain the culture. The Sociedad de Protección Mutua de Trabajadores Unidos, for example, continues to sponsor local societies in northern New Mexico, the San Luis Valley of southern Colorado, and an urban affiliate in Denver. These "concilios locales" follow a common Código Ritualistico de Regimen Interior (Code of Internal Rituals, Revised 1980) for the conduct of their meetings and in the performance of rituals during burial ceremonies for deceased hermanos. Participation in burial services continues as has been the tradition since the founding of the society and is viewed as an obligation and a ritual of profound honor and respect. Much as before, officers of the local councils conduct the meetings in the native Spanish language and in the order prescribed in the rules: ceremonia de apertura, oración oficial, lectura de los procedimientos de la previa reunión, comunicaciones y reclamos, reportes de comisiones, ceremonia de admisión de nuevos miembros, negocios sobre la mesa del Presidente, debates para el bien de la Sociedad, reporte de colectaciones, y de embolsos y delincuencias de miembros, ceremonia de clausura.

\section{Acequia resilience and the heritage of mutualism}

"Irrigation is man's response to drought; by this means he reduces radically the uncertainty that nature presents to buman settlement in an inhospitable environment. To succeed for any length to time, to capture and distribute available water, and to control the amount of land placed under irrigation, farmers must develop self-discipline and a bigh level of community organization.” (Maass and Anderson, 1978)

Similar to cofradias and mutualistas, the community acequias evolved from the traditions of cooperation and the pooling of resources for the pursuit of common objectives, in this case the economic need to establish agricultural settlements along the upper Río Grande and tributaries. As gravity flow systems, acequias take water out of the streams only when 
surface water is available, whether in times of abundance or scarcity, each time adapting to local environmental conditions. The practice of repartimiento insures that all farmers share the water supply based on a system of rotation that is flexible and equitable. In times of abundancia, all headgates are opened and everyone is free to take water from early spring run-off to moisten the dry soil, nourish the shrubs and trees along the ditch bank, and fill stock ponds, a process that also recharges shallow domestic wells in the community (Fernald et al 2012). In dry years the schedule of water turns is tightened to insure a minimum quantity of water for each irrigator. Water sharing and adaptive capacity, coupled with decision-making authority at the local level, have been among the major factors that account for the resilience of acequias.

In most watersheds, the acequias are the first diversions in the system, and therefore, the officers can respond quickly to seasonal changes in snow pack conditions and spring runoff into the streams and rivers. During times of water scarcity or years of prolonged drought, for example, the system of turns for water delivery can be modified according to customs and traditions of repartimiento, auxilio, and allocation of sobrantes. Agreements on how to divide the water within and across acequias may be reviewed and altered to fit existing conditions in the stream season to season. Decisions of this kind are made at open meetings of the parciantes to insure transparency and compliance with any new or modified rules of water distribution. When violations occur, the acequias impose fines, curtail water deliveries, or take other appropriate measures to enforce and uphold the rules. In all of these respects, the acequia farmers control their own destinies by acting collectively, the dominant characteristic found in case studies of successful irrigation communities and long enduring common property systems operating in other world desert environments (Maass and Anderson 1978; Ostrom 1992).

Many factors have contributed to system resiliency, but the concept of mutualismo, reciprocal mutual aid, has to be included among one of the essential foundations of community cohesion evidenced in the three forms of societies examined here. In times of hardship or other needs, voluntary associations mobilized local resources and bonded the residents into a collective imaginary deeply rooted in the land. Rituals, democratic participation in governance, and continuity of culture have maintained solidarity and retained the identity of the land-based people of the upper Río Grande, the essence of "querencia" described to perfection by Juan Estevan Arellano (1997) when he wrote: "El que pierde su tierra, pierde su memoria" (He who loses his land, loses his memory). Querencia is what anchors people to the land and this attachment in turn inspires mutualism across neighbors and kin who live in the same place. After a lifetime of learning about wisdom of the land and knowledge of the water from his elders and mentors, Arellano, the former mayordomo of the Acequia Junta y Ciénaga on the Río Embudo, concludes that healthy bioregions and strong rural economies depend on safeguarding land, water, and people as a common interest and not as the private property of individuals (Arellano 1997, 2014).

The lay sodalities of penitentes and the secular sociedades mutualistas of the last century have declined in numbers, but the heritage of mutualism thrives in the hundreds of "riegos ancestrales" that survive in the acequia landscapes of New Mexico and southern Colorado (Martínez Saldaña 2011). This heritage includes multiple patterns of collective labor and reciprocity that take place at the start of and throughout the yearly irrigation cycle: the social organization for water management to accomplish the common objective of irrigation from a shared water source; repeated actions of mutual help that keep the organizational structure robust and prevent its collapse; reliance on elders with knowledge and experience to transmit customs and traditions to new generations; rituals and use of 
the Spanish language that bond the community such as the annual ditch cleaning in the early spring and in some communities religious ceremonies and processions to bless water sources and other sacred landscapes on día de San Ysidro or feast days for the village patron saint; and a sense of communitarian responsibility for those unable to tend to the acequia duties such as widows or handicapped persons exempting them from work days to clean or repair the ditch infrastructure. Together, these bonds of mutuality and social participation in events that celebrate the culture reinforce identity not as an individual trait but as a regional people with a common history and shared institutions, a form of "corporatism" that stresses membership in the group as the basis of interpersonal relations (Briggs 1988).

\section{Discussion and Conclusions}

Will the acequias de comun survive the multitude of stressors working against small-scale agriculture not only in the upper Río Grande but in the global economy as well? Are there "tipping points" (hydrologic, economic, social) that are beyond the capacity of the acequias to resolve, and can these threats be averted? Solidarity, community cohesion, and mutuality are important elements of system renewal to counter threats that may surface periodically, but in the long term, customary practices are knowledge based and need to be handed down by the elders in the native Spanish dialect of the parciantes and mayordomos, not just in the English dominant language. Cultural practices, along with environmental knowledge, are embedded in the lexicon of the acequia and these concepts do not translate readily (Arellano 2013, 2014). Examples of social memory and local knowledge held by the elders include: how to classify the anatomy of an acequia from the headwaters in the sierra down to the presa and from there to the network of madres and cabeceras carved into the valley bottomlands; how and when to open and close compuertas along the acequia and into the desagïe channel for return flow to the river; how to design repartimientos and other flow sharing procedures that are equitable and adaptable to environmental conditions during wet and dry seasons; and how to move with the water once diverted from the acequia madre into the linderos that carry water into the huertos, milpas, and vegas (Arellano 2014).

In his many decades of studying the cultural meaning of ancient hydraulic landscapes worldwide, Glick (2006) advocates for the preservation of huertas, oases, polders, and chinampas as significant human artifacts that have been stable, long term providers of food. According to Glick, traditional agricultural systems are knowledge intensive, and the complete system is carried collectively in the local knowledge of the irrigators, particularly with regard to the distinctive micro region of their community: soils, climatic conditions, crops, and water requirements for every niche suitable for agriculture. The social cohesion of the irrigators, along with a strong sense of communal responsibility, derives not from values of economic efficiency but from the values encoded in the operational rules of water sharing, namely, equity, justice, and local control, all attributes of a "shared institution." Once these and other customary practices are lost, Glick predicts that the intensive local knowledge can never be recovered (Glick 2006).

If there is a fatal tipping point that might signal the collapse of the upper Río Grande acequias, it could be the loss of the Spanish language, already an endangered form of communication as the number of knowledge carriers, the Spanish fluent parciantes and mayordomos, declines each generation and there are fewer youth to take over (Arellano 2013). There is no easy solution to reverse this trend, but clearly we recognize that the transmission of local agricultural knowledge goes hand in hand with keeping the acequia as a living institution. Fortunately, with English dominant bilinguals, a demographic majority 
after World War II, Spanish words and phrases take on iconic value when incorporated into the everyday speech characterized by code switching. Since acequia culture is rooted in customary practice and the ancient moral economy of water, the Spanish terms in which values are encoded continue to inspire respect for tradition and ancestral knowledge among the youth of today. The basic terminology in the language of the acequia sticks with children and young people. La presa, compuerta, mayordomo, la limpia, tarea, pala, cosecha and a host of other terms convey iconic meaning when grandparents or other elders in the community engage youth in pedagogical discourse about the bygone days of the ancestors, "los viejitos de antes" (Briggs 1988). We propose that the best way to preserve the acequias is to keep them alive as food producing systems, and that we teach, learn and relearn the lexicon of the acequia in native Spanish as a heritage language alongside the use of English. Language recovery programs should be instituted at all levels of education, K-12 plus community colleges and universities.

We conclude with a set of propositions that characterize system resiliency of acequia governance and may hold the key to adaptation when new challenges emerge in future scenarios of unexpected change. These conclusions stem from multidisciplinary research in progress (Fernald et al 2012) studying the connectivity of coupled hydrologic and human systems as the basis of resilience in traditional irrigation communities of the upper Río Grande:

(a) The acequia culture is based on a reciprocal relationship between irrigation and community that creates a sense of place, attachment to the land, and a shared cultural identity based on membership in the corporate group;

(b) Mutual networks and social density result in cooperation over water sharing when acequias are confronted with drought or other stressors from outside the community;

(c) Customary practices combine hydrologic and sociocultural strategies encoded in the acequia culture to respond collectively to snow melt releases in the spring and variable precipitation during the summer months;

(d) Autonomy of the decision making structure in acequia governance permits rapid adjustments in the operational rules and practices of each acequia when warranted by changing environmental conditions of wet or dry seasons;

(e) Traditional knowledge of local ecology and customary practices in Spanish and English are vital components of social capital for transmission to the next generation, a process essential to the continuity of acequia agriculture and culture.

\section{Acknowledgments}

The early work that led to the development of this essay came from a presentation at the "4th Annual Celebrando las Acequias: Water + Resilience," sponsored by the Arid Lands Institute of Woodbury University, and hosted by Juan Estevan Arellano, Embudo Mission, Dixon, New Mexico, June 10-12, 2011. Additional work was conducted from 2010-2014 supported by a research grant made by the National Science Foundation to New Mexico EPSCoR, award \#0814449 and a second grant to New Mexico State University, award \#101516 with a subaward to the Center for Regional Studies at the University of New Mexico. Other collaborators in the NSF research included the New Mexico Institute of Mining and Technology, Sandia National Laboratories and the New Mexico Acequia 
Association. For information about current issues vital to the acequias, consult the website of the New Mexico Acequia Association http:/ /www.lasacequias.org.

\section{References}

Archuleta, R.E. (2003): Land of the Penitentes, Land of Tradition, El Jefe, Pueblo West, Colorado.

Archuleta, R.E. (2007): Penitente Renaissance: Manifesting Hope, El Jefe, Pueblo West, Colorado.

Arellano, J.E. (1997): La Querencia: La Raza Bioregionalism, New Mexico Historical Review 72: 31-37.

Arellano, J.E. (2013): New Mexico Acequia Workshop Arellano Presentation, Acequias and the Future of Resilience in Global Perspective Symposium, Las Cruces, New Mexico, March 2-3. http://www.culturalenergy.org/listenlinks.htm (accessed May 20, 2014)

Arellano, J.E. (2014): Enduring Acequias: Wisdom of the Land, Knowledge of the Water, University of New Mexico Press, Albuquerque, New Mexico.

Barker, S.O. (1924): Los Penitentes, Overland Monthly, 82: 180, cited in J.A. Hernández, Mutual Aid for Survival (1983), Krieger Publishing Company, Malabar, Florida.

Briggs, C.L. (1988): Competence in Performance: The Creativity of Tradition in Mexicano Verbal Art, University of Pennsylvania Press, Philadelphia, Pennsylvania.

Buxó i Rey, M.J. (1997): El mutualisme com a narració de la identitat: La Societat de Protecció Mútua de Treballadors Units a Nou Mexic (EAU), Revista d'etnologia de Catalunya, 11: 68-77.

Buxó i Rey, M.J. (2003): "El paisaje cosmológico de la arquitectura en el Suroeste de Norteamérica," Revista Española de Antropología Americana, vol. extraordinario: 85-98.

Fernald, A., Tidwell, V., Rivera, J., Rodríguez, S., Guldan, S., Steele, C., Ochoa, C., Hurd, B.,

Ortiz, M., Boykin, K., and Cibils A. (2012): Modeling Sustainability of Water, Environment, Livelihood, and Culture in Traditional Irrigation Communities and Their Linked Watersheds, Sustainability, 4: 2998-3022.

Glick, T.F. (1970): Irrigation and Society in Medieval Valencia, Harvard University Press, Cambridge, Massachusetts.

Glick, T.F. (2003): Thin Hegemony and Consensual Communities in the Medieval Crown of Aragon, in M. Barceló, et al Eds., El feudalisme comptat $i$ debatut: Formació $i$ expansió del feudalisme català, Universitat de Valencia, Museu D' História de Catalunya: 523-538.

Glick, T.F. (2006): Historical Status and Cultural Meaning of Historic Hydraulic Landscapes: Oases, unpublished paper, First International Congress on Oases and Sustainable Tourism, Elche, December 15, 2006. 
Glick, T.F. (2013): New Mexico Acequias as Living Simulacra of Medieval Peninsular Irrigation Communities, unpublished paper, $44^{\text {th }}$ Annual Meeting of the Association for Spanish and Portuguese Historical Studies, Albuquerque, New Mexico, April 4-7, 2013.

Kessell, J.L. (1989): Remote Beyond Compare: Letters of Don Diego de Vargas to His Family from New Spain and New Mexico, University of New Mexico Press, Albuquerque, New Mexico.

Knowlton, C.S. (1969): Changing Spanish-American Villages of New Mexico, Sociology and Social Research, 53: 455-474.

Kutsche, P. and D. Gallegos (1979): Community Functions of the Cofradía de Nuestro Padre Jesús Nazareno, in P. Kutsche, Ed., The Survival of Spanish American Villages, Colorado College Studies: 15: 91-98.

Lamadrid, E.R. (2008): Rutas del Corazón: Pilgrimage and Cultural Commerce on the Camino Real de Tierra Adentro, New Mexico Historical Review, 83: 423-449.

Laws of the Indies, (1593): Ordenanzas de descubrimiento, nueva población de las Indias dadas por Felipe II en 1573, in Crouch, D. P. et al., Spanish City Planning in North America., MIT Press, Cambridge, Massachusetts, 1982.

Leonard, O.E. (1970): The Role of the Land Grant in the Social Organization and Social Processes of a Spanish-American Village in New Mexico, Calvin Horn Publisher, Inc., Albuquerque, New Mexico.

Maass, A., and R.L. Anderson (1978): . . . and the Desert Shall Rejoice: Conflict, Growth and Justice in Arid Environments, MIT Press, Cambridge, Massachusetts.

Martínez Saldaña, T. (1998): La Diáspora Tlaxcalteca: Colonización agrícola del norte mexicano. Tlaxcallán, Ediciones del Gobierno del Estado de Tlaxcala, Tlaxcala, México.

Martínez Saldaña T. (2004): Colonial Irrigation Systems in Northern New Spain, in J.E. Arellano, Ed., El Caminante, 3: 22-26.

Martínez Saldaña T. editor general (2011): Riegos Ancestrales en Iberoamérica; técnicas y organización social del pequeño riego, Biblioteca básica de agricultura primera reimpresión, Colegio de Postgraduados, UACH, INFAP, IICA, Mundi Prensa México.

Martínez Saldaña, T. and J.A. Rivera (2008): Cofradías y mutualidades en el norte de la Nueva España: la organización en torno a los sistemas de riegos coloniales, Boletín del Archivo Histórico del Agua, Año 13, Número 38: 8-16.

Meyer, M.C. and M.M. Brescia (1998): The Treaty of Guadalupe Hidalgo as a Living Document: Water and Land Use Issues in Northern New Mexico, New Mexico Historical Review, 73: 321-345.

Ostrom, E. (1992): Crafting Institutions for Self-Governing Irrigation Systems, ICS Press, San Francisco, California. 
Peña, D.G. (1998): Cultural Landscapes and Biodiversity: The Ethnoecology of an Upper Rio Grande Watershed Commons, in V.C. de Baca, Ed., La Gente: Hispano History and Life in Colorado, Colorado Historical Society, Denver, Colorado: 241-271.

Rivera, J.A. (1998): Acequia Culture: Water, Land, and Community in the Southwest, University of New Mexico Press, Albuquerque, New Mexico.

Rivera, J.A. con traducción de Luis Pablo Martínez (2009): La Cultura de la Acequia: Agua, tierra y comunidad en el Suroeste de los Estados Unidos de América, Universitat de València.

Rivera, J.A. (2010): La Sociedad: Guardians of Hispanic Culture Along the Río Grande, University of New Mexico Press, Albuquerque, New Mexico.

Rodríguez, S. (2006): Acequia: Water Sharing, Sanctity, and Place, School of Advanced Research Press, Santa Fe, New Mexico.

Rosenbaum, R.J. (1981): Mexicano Resistance in the Southwest: The Sacred Right of Self-Preservation, University of Texas Press, Austin, Texas.

Steele, T.J. and R.A. Rivera (1985): Penitente Self-Government: Brotherhoods and Councils, 17971947, Ancient City Press, Santa Fe, New Mexico.

Weber, D.J. (1973): Foreigners in their Native Land: Historical Roots of the Mexican-Americans, University of New Mexico Press, Albuquerque, New Mexico

Weigle, M. (1970): The Penitentes of the Southwest, Ancient City Press, Santa Fe, New Mexico.

Weigle, M. (1976): Brothers of Light, Brothers of Blood: The Penitentes of the Southwest, University of New Mexico Press, Albuquerque, New Mexico. 